\title{
British colonialism and the criminalization of homosexuality
}

Article

Accepted Version

Han, E. and O'Mahoney, J. (2014) British colonialism and the criminalization of homosexuality. Cambridge Review of International Affairs, 27 (2). pp. 268-288. ISSN 1474-449X doi: https://doi.org/10.1080/09557571.2013.867298 Available at https://centaur.reading.ac.uk/80592/

It is advisable to refer to the publisher's version if you intend to cite from the work. See Guidance on citing.

To link to this article DOI: http://dx.doi.org/10.1080/09557571.2013.867298

Publisher: Taylor \& Francis

All outputs in CentAUR are protected by Intellectual Property Rights law, including copyright law. Copyright and IPR is retained by the creators or other copyright holders. Terms and conditions for use of this material are defined in the End User Agreement.

\section{www.reading.ac.uk/centaur}

\section{CentAUR}

Central Archive at the University of Reading

Reading's research outputs online 


\section{British Colonialism and the Criminalization of Homosexuality}

\section{Introduction}

The politics of gay rights has been a contested issue in many countries in the world. Lesbian, Gay, Bisexual, and Transgender (LGBT) activists and human rights movements have coined the idea that gay rights are the last bastion of civil rights in modern democracies. ${ }^{1}$ On December 6, 2011, U.S. Secretary of State Hillary Clinton stated at the United Nations Human Rights Council in Geneva that gay rights and human rights are 'one and the same.'2 Like the politics of racial discrimination in previous decades, legal discrimination against homosexuals in Western democracies has indeed been interpreted as a serious challenge to the ideal of democratic sovereignty and citizenship, and thus should be eliminated (Goldberg-Hiller, 2005). Particularly, politics of same-sex union has become one of the main contested issues in many Western countries.

Yet, at a time when public discourse on LGBT rights in the West has overwhelmingly focused on the same-sex union issue (Kollman, 2007), across the globe there are still many countries where homosexual conduct is criminalized with different levels of legally mandated punishment. In May 2010, a gay couple in Malawi was found guilty of 'unnatural acts' and faced charges of up to 14 years in prison, under sections 153 and 156 of Malawi's criminal code (Bearak, 2010). Worse still is that in some countries, homosexual conduct can even lead to death penalty. In September 2011, three men were executed for sodomy in Iran. Most recently, four more Iranian gay men were sentenced to death by hanging for sodomy in 2012 (Littauer, 2012). These were all undertaken with reference to articles 108 and 110 of the Islamic Penal Code.

Such punishment of homosexual conduct notwithstanding, in many other countries society's attitudes towards the LGBT community are becoming ever more tolerant, and 
indeed many countries have already decriminalized homosexual conduct. On July 3, 2009, New Delhi's High Court ruled that homosexual conduct should not be deemed a criminal offense, challenging more than a century of criminalization of homosexuality in India since the British introduced the India Penal Code (IPC) in 1860. After the ruling, scholars have indeed found evidences that this decriminalization has led to a rise in the level of social acceptance and self- acceptance of homosexuality in India (Jain, 2013). Similarly in December 2011, the leader of the Turkish Cypriot Government in Northern Cyprus agreed to repeal a law criminalizing homosexuality after international outcry over the arrest of several men for 'homosexual offenses' (Canning, 2011). This was the last government in Europe to have a law banning homosexuality.

What explains the variation in laws regulating and punishing homosexual conduct around the world? Why do some countries continue to have legislations that criminalize homosexuality while others have put that into the past? One of the hypotheses put forward for why some countries have laws that criminalize homosexual conduct and others do not is that colonialism is in some way responsible. Elsewhere the practice and experience of western colonialism have been theorized as deeply tied to conceptions of sexuality (e.g. McClintock, 1995; Stoler, 2002; Aldrich, 2003). However, particularly pertinent to our inquiry are two claims usually made concerning colonial origin and criminalization of homosexual conduct. The first claim, which has recently attained popularity, is the idea that the British Empire was responsible for spreading laws that criminalize homosexual conduct amongst its colonies, whereas other imperialists did not (Tielman and Hammelburg, 1993; Gupta, 2008; Frank et al, 2009; Sanders, 2009). The second claim is that there is some legacy of the British colonial experience that has made it less likely for countries that are ex-British colonies to decriminalize homosexual conduct (Wilets, 1994). The claim is that not only did the British bring such laws to their 
colonies, but that they 'poisoned' the prospects for liberalization and the repeal of those laws.

This article is an attempt to investigate these two claims using systematic data analysis. We utilize a newly constructed dataset that includes the most up-to-date data on 185 countries to assess the overall evidentiary basis for the two claims above. We find that British colonies are much more likely to have laws that criminalize homosexual conduct than other colonies or other states in general. This result holds after controlling for numerous variables that might be expected to influence the likelihood of repressive LGBT rights legislation. However, we also find that the evidence in favor of the claim that British imperialism 'poisoned' societies against homosexuality is inconclusive at best. The speed of decriminalization of homosexual conduct for those colonies with such a law is not systematically slower for British colonies compared to colonies of other European states. This suggests that the stickiness of repressive institutions is relatively constant and not a product of a particular type of colonialism.

The article is organized as follows: First we present up-to-date data on the legality of homosexuality around the world, demonstrating the extent of the continuing criminalization of homosexual conduct in many countries. Then we examine British colonialism, focusing squarely on how the British imposed a specific set of penal codes on its former colonies around the world that particularly targeted homosexual conduct as punishable by law. We use the existing literature on the role of British colonialism in the criminalization of homosexual conduct to generate empirical hypotheses. We then proceed to statistical testing of our hypotheses and interrogate the data to further assess the findings. The article concludes with further reflections about LGBT politics and the theoretical contributions of our study.

\section{Global Legal Situation of LGBT Rights}


Male to male sexual conduct in the form of sodomy used to be and still is a punishable crime on the law books of many countries in the world. ${ }^{3}$ In the United Kingdom, sodomy was first decriminalized in England and Wales in the 1967 Sexual Offences Act, and then in Scotland in 1980 and Northern Ireland in 1982. In the United States, fourteen states had laws against sodomy until the Supreme Court ruling on Lawrence v. Texas in 2003. While many countries have so far decriminalized sodomy, homosexual conduct still remains a crime in 76 countries in the world by 2011 according to the International Lesbian, Gay, Bisexual, Trans and Inter sex Association (ILGA). ${ }^{4}$ Most of these laws target male to male sexual relationships, while only a few countries also criminalize female to female ones (ILGA). According to the information provided by ILGA, there are different types of punishment for homosexual conduct: fines or restrictions or penal labor, imprisonment, and the death penalty. As we can see from Table 1, most countries in this group consider homosexual conduct punishable by imprisonment. Only in 8 countries is homosexual conduct considered severe enough for punishment by death penalty. For example, the Islamic Penal Code of Iran of 1991 states 'sodomy involves killing if both the active and passive persons are mature, of sound mind and have free will. $^{5}$

\section{TABLE 1 HERE}

\section{British Colonialism and LGBT Rights}

There has been a rich literature detailing the impact of colonialism on the rest of the world (Boon, 1992; Mamdani, 1996; Amsden, 1989; Wade, 1990; Kohli, 2004; Huff, 1994). For some, western colonialism is at the very root of underdevelopment in the developing world, because colonial powers not only plundered natural resources of the colonies, but 'colonialism created ineffective legal-administrative institutions, empowered local chiefs and notables, and thereby institutionalized decentralized and 
despotic systems of control' (Lange, 2009, p. 9). Furthermore, western colonialism has been blamed for the impoverishment, violence, and destruction of indigenous forms of knowledge, culture and property. However for many others, the legacies of western colonialism are much more nuanced. Instead, many studies have found that the identity of the colonizer matters a great deal for the socioeconomic and cultural institutions of postcolonial societies (Fieldhouse, 1966; Landes, 1998; Miles, 1994; Pagden, 1995; Young, 1994), which in turn affect economic growth rates of these countries (Alam, 1994; Grier, 1999; Bertocchi and Canova, 2002). Others have also found that different colonial experiences are closely associated with countries' democratic credentials and survival (Bernhard et al, 2004; Olsson, 2009).

Particularly, much ink has been spilled on the putatively positive contribution British colonialism has brought to many a country that Britain once colonized (D'Souza, 2002; Ferguson, 2002). Lange et al (2006), for example, argue that the colonialism of liberal Britain, in comparison with mercantilist Spain, tended to produce positive effects in its colonies' economic development. That is, British colonialism spread a liberal model that 'organizes productive activity toward maximizing profit through exchange in free markets...[and] political authorities use the state to uphold private property, encourage commercial production, and enforce the rule of law' (Lange et al, 2006, p.1416). The common law legal system introduced or imposed by the British has also been lauded for its better protection of property rights and contribution to better government performance as well as being a better guarantee for freedom (La Porta et al, 1999; La Porta et al, 2004). Furthermore, British colonialism has been credited for its positive legacy on democratic development in its former colonies (Blondel, 1972; Huntington, 1984; Lipset et al, 1993). The parliamentary system, election for local self-governing bodies, superior infrastructure, and indirect ruling style, have all been pointed out as indicators of the 
benign British colonial legacy and causes for healthier democratic development in former British colonies (Bernard et al, 2004).

However, we may note one particular dark legacy left by the British colonial history. That is, British colonialism might have been especially detrimental towards LGBT rights in colonial societies. From 1860 onwards, the British Empire spread a specific set of legal codes throughout its colonies based on the colonial legal codes of India and Queensland, both of which specifically criminalized male-to-male sexual relations, though by long-term imprisonment rather than death. ${ }^{6}$ For example, Section 377 of the Indian Penal Code (IPC) read as follows:

Section 377: Unnatural offences - Whoever voluntarily has carnal intercourse against the order of nature with any man, woman or animal shall be punished with imprisonment for life, or with imprisonment ...f for a term which may extend to 10 years, and shall be liable to fine.

Explanation - Penetration is sufficient to constitute the carnal intercourse necessary to the offense described in this Section. ${ }^{7}$

The IPC was the first comprehensive codified criminal law produced anywhere in the British Empire (Friedland, 1992, p.1172). Fearful that its 'soldiers and colonial administrators - particularly those without wives at hand - would turn to sodomy in these decadent, hot surroundings,' the British Empire drafted the IPC with the intention of both protecting the Christians from 'corruption' as well as correcting and Christianizing 'native' custom (Gupta, 2008, p.16). At the time, British colonial judicial officers were often inexperienced lay magistrates without legal resources and relied upon importing extant examples of criminal regulations. Thus, the IPC, together with the Queensland Penal Code of 1899 (QPC), became the model for British colonies' legal systems, and was exported and imposed on various other British colonial acquisitions throughout Asia and Africa (Morris, 1974). Thus, through its colonial administration, the British managed 
to impose and institutionalize a set of legal codes in its colonies that criminalized homosexual conduct.

In contrast with the British experience, the other big colonial power - France - arguably did not leave such an institutional legacy on criminalization of homosexual conduct. Due to developments in Enlightenment concepts of liberty and rights after the French Revolution, the French penal code of 1791 decriminalized sodomy between over-age consenting adults in private. This code was subsequently spread by Napoleon's conquests in continental Europe and through the French Empire (Frank et al, 2009, p. 533). Therefore, the French presumably did not leave such an institutional legacy on its colonies as the British. These historical institutional legacies may have had more of an influence on current national laws than other factors that are more specific to LGBT rights in particular. Sanders takes a strongly stated position on the role of colonialism; 'Of the great colonial powers of Western Europe - Britain, France, Germany, the Netherlands, Portugal and Spain - only Britain left this legacy to its colonies' (Sanders, 2009, p.1). The claim that countries once colonized by the British are more likely to have such criminalization legislation in their law books is prominent in the literature. However, such a claim has so far not been evaluated systematically.

The literature on institutions has often emphasized how institutions can generate path dependence and thus can make changes to the status quo difficult to achieve (Mahoney, 2000; Pierson 2000). Therefore, another bold position on the influence of the British colonial experience on LGBT rights is that not only did the British bring the laws that criminalize homosexual conduct to their colonies, but that they somehow 'poisoned' the prospects for liberalization and repeal of those laws. Legal scholars have studied law's ancillary effects on social structure and individuals' lives. For example, Ryan Goodman applies these ideas to sodomy laws. Based on a study of South Africa, he argues that the 
criminalization of sodomy can have numerous effects on the social status of LGBT people. This in turn can affect their individual identity, their social relations, conceptions of public space and the capacity to associate, and other discourses in society. As an example of the latter, religious leaders can point to the state's condemnation of same-sex practices as proof of the sentiment of the general community. This is used as support for their assertions that these practices are immoral (Goodman, 2001, p.723). Several scholars have argued that effects like these are more prevalent in ex-British colonies than in other colonies. For example, Tielman and Hammelburg argue that 'From a historical perspective, the English legislation against homosexuality has had (and unfortunately still has) appalling consequences for the legal position of homosexual men, and, to a lesser extent, lesbians in the former British colonies. The effects of the former French, Dutch, Spanish, and Portuguese colonial legislation against homosexuality are less severe.' (Tielman and Hammelburg, 1993, p. 251.) Wilets also claims that the effects of colonialism even after independence are such that Caribbean nations, mostly ex-British colonies, have 'extraordinarily high levels of anti-LGBT social animosity and repressive legislation' whereas Latin American nations, mostly ex-Spanish colonies, do not (Wilets, 2010, p. 249). This argument is essentially that British colonialism not only spread such laws, but also created long term barriers to decriminalization.

\section{Research Questions and Hypotheses}

Are ex-British colonies more likely to have laws that criminalize homosexual conduct? The first research question can be answered by looking at the current state of LGBT rights legislation around the world. Existing studies have not used statistical techniques to control for other factors that are potentially correlated with levels of LGBT tolerance or repression. We use data on a variety of variables to provide evidence relevant to the following hypothesis: 
H1: States with a British legal origin are more likely to have a law criminalizing homosexual conduct.

Our second research question concerns the legacy of colonialism post-independence. Do British colonies have a harder time decriminalizing homosexual conduct laws once they are free of the 'imperialist yoke'? This is a complex question, but there are simple ways of using the existing data to provide suggestive conclusions. If it is harder for a state to decriminalize homosexual conduct, then it should take longer, ceteris paribus, for such a state to do so. Therefore, if British colonialism has entrenched homophobia deeper than other colonies, it should have taken longer for British colonies to decriminalize than other states, or colonies of other imperialists. One way of operationalizing this idea is to look at the length of time between a colony gaining independence and decriminalization of homosexual conduct.

This leads to the following hypothesis:

H2: States with a British legal origin have a longer time in between gaining their independence and decriminalizing homosexual conduct.

However, since the 1960s there has been a global trend toward decriminalization of homosexual conduct. Frank et al explicitly address the issue of the worldwide trend towards the decriminalization of sodomy (Frank et al, 2009). Based on a dataset of legal changes since 1945, including expansions and contractions in the scope of the criminal regulation of sodomy, they argue that domestic-level factors are insufficient to explain the liberalization of sodomy regulation on a global scale in a short period of time. Instead, they turn to a world society perspective and claim that the world culture is becoming more tolerant of homosexuality in general. This argument rightfully noticed the global trend towards decriminalization of homosexual conduct, however by itself it is 
unable to account for variation in the continuation of criminalization of homosexual conduct among various countries in the world to this day. That means a world society type of argument cannot easily explain why certain countries still maintain such laws. This is especially true for variation associated with colonial heritage. There is no reason why ex-British colonies would be less open to the influences of global culture. In fact, given their relatively high level of economic development and civil liberties, they are probably more receptive to global society than other countries that have less access. However, if there is a global move towards acceptance of homosexuality, then merely looking at the time between independence and decriminalization risks omitting a crucial variable if colonies gained independence at different points in world time, which they did. In order to deal with this issue, we also look at whether British colonies have decriminalized homosexual conduct later in world time than others. This motivates an alternative operationalization of the concept of time to decriminalization, providing the following hypothesis.

H3: States with a British legal origin take longer to decriminalize after 1945.

We chose 1945 because we wanted to focus on the modern era; and it seems reasonable to argue that the post WWII represents a clear juncture in world history that some fundamental changes occurred in the international system. If $\mathrm{H} 2$ or $\mathrm{H} 3$ are not borne out in the data, then this is evidence against the idea that British colonialism uniquely created barriers to the decriminalization of homosexual conduct. If indeed $\mathrm{H} 2$ or $\mathrm{H} 3$, or both, are supported by our empirical analysis, then we can be more confident in stating that British colonialism created political and social legacies that have made repeal of those laws more difficult.

\section{Data and Methodology}


Data for our analysis come from several sources. The dependent variable criminalization of homosexual conduct - comes from the ILGA's website. We coded this dependent variable in two ways. First we constructed a dummy variable -1 indicating criminalization of homosexual conduct is present and 0 otherwise. We also constructed an ordinal variable following the coding scheme provided by the ILGA's website - that is 4 for death penalty, 3 for imprisonment of more than 10 years, 2 for imprisonment of less than 10 years, 1 for fines or restrictions or penal labor, and 0 for none. All the coding here follow strictly ILGA's own coding, and we cut off the time by the end of summer 2010.

Given the central importance of the colonialism variable, we used several different measures. Initially, we used the legal system origin data compiled by La Porta et al. (La Porta et al, 1999). This data is widely considered to be the most systematically collected data on the colonial origins of legal systems. Given that our research concerns the legal status of LGBT rights, this seemed to be an appropriate measure. However, we also used other measures of colonial experience, in order to see if the results were sensitive to this particular coding. The coding for the other colonialism variables was taken from a variety of sources. One was Bernhard et al, who had coded British, French, Spanish, Dutch, Portuguese, and US colonial possessions (Bernhard et al, 2004). Lange et al (2006) coded British and Spanish colonies only, and Klerman et al (2011) coded British and French colonies as well as countries not colonized by the French but that had adopted French Civil Law codes. The variable for whether a state had been a colony was the union of the sets of overseas western colonies identified in our three main sources (by Bernhard et al or Lange et al as British or Spanish, or Klerman et al as British or French). ${ }^{8}$ This categorization excludes Soviet, German, US, and Belgian colonies. Soviet Socialist Republics were not colonized or decolonized in the same way as other colonies and their inclusion would bias the results. There were not enough German, 
American or Belgian colonies to draw meaningful statistical results. The key variable of whether a state was a British colony was the union of the sets of British colonies identified by Bernhard et al, Lange et al, and Klerman et al. We used Klerman et al's coding of French colonies, as Klerman et al had the most comprehensive list.

For the specific dates of decriminalization of homosexual conduct, we aggregated data from several sources. The data came from Waaldijk (2009), Bruce-Jones and Itaborahy (2011), and Frank et al (2010). Differences between codings in these sources were almost entirely in terms of coverage, rather than different dates. Where these sources conflicted, we applied a majority rule; i.e. one source was overruled by two sources.

For the question of whether some states took longer between independence and decriminalization than other states, we needed to know when states became independent. The coding for the start date of states was taken from the Polity dataset and supplemented by the authors' own coding for those states not covered by the Polity dataset.

In addition, our dataset includes a set of control variables. One commonly posited theory about social tolerance and attitudes towards homosexuality is the modernization and most-modernization theory proposed by Inglehart $(1987 ; 1990 ; 1997)$. Therefore, one might expect a positive relationship between economic development and tolerant policies towards homosexual conduct. Other studies have also shown attitudes towards homosexuality are highly correlated with economic inequality in a given country (Andersen and Fetner, 2008). Thus, we also control for countries' economic inequality using the Gini index. Religion is also commonly considered to be an important factor in the legal treatment of LGBT people (Burack, 2008; DeYoung, 2000; Herman, 2000; Schmitt, 1992; Duran, 1993). There are two ways religion can manifest in policies towards homosexuality: one is the overall level of religiosity of a given country, and the other is that country's dominant religious denomination. The measurement of religiosity 
comes from the World Values Survey, which is an eight-category index of religious institution attendance. To measure religious denominations for countries, we used the Fractionalization data compiled by Alesina et al (2003). Furthermore, we can also think that a country's regime type may also matter as to whether laws that criminalize homosexual conduct exist in its law books. Democracies are probably less likely to persecute homosexuality than authoritarian ones, presumably due to democratic countries' tolerance towards minorities, their emphasis on equal rights, and their tendency to protect fundamental human rights (Inglehart and Welzel, 2002; Kymlicka, 1995). To measure the level of democracy and authoritarianism for each country in our dataset, we used the Polity dataset.

We also believe a set of international variables need to be controlled. As the world is increasingly interconnected, the social aspect of globalization means more intensive transmission of ideas and information from the outside world. Thus, we can expect that countries that are most open to the outside world - embodying 'cosmopolitan culture' as phrased by Norris and Inglehart - are most likely to decriminalize homosexual conduct (Norris and Inglehart, 2009). To measure countries' openness to cosmopolitan values, we used Internet usage as a proxy, for which we used the number of Internet users per 100 people. Data for Internet usage is from the World Bank Development Index. Finally, international human rights regime might also play role here. The continuation of laws that criminalize homosexual conduct in many countries has become a target of international human rights campaign. For example, Amnesty International, Human Rights Watch, and many others have devoted campaigns for the decriminalization of homosexual conduct, and called for the release of anyone imprisoned solely for homosexuality as prisoners of conscience (Amnesty International, 2008). Therefore, we believe countries that are most open to international human rights norms are the ones most likely to decriminalize homosexual conduct. To measure the influence of the 
international human rights regime, we used the number of major human rights, humanitarian, disarmament, and environmental treaties ratified by countries, which we sourced from Global Civil Society (Anheier, 2006).

Our main model for the current legal status of homosexual conduct uses a dummy variable for whether there is a criminalization of homosexual conduct and we estimate the coefficients of the independent variables using logistic regression with robust standard errors. As our data on religiosity is limited to less than half of the cases, we estimate the model separately after controlling for religiosity. We also use an ordinal dependent variable, which includes the severity of legal punishment, and estimate the models using ordinal logit. For the models using time to decriminalization, an interval variable, as the dependent variable, we estimated linear regression models with robust standard errors. For a list of descriptive statistics of our variables, see Table 2. Results for our first set of models addressing H1 (concerning the contemporary distribution of laws that criminalize homosexual conduct) are reported in Table 3.

\section{TABLE 2 HERE}

\section{TABLE 3 HERE}

\section{The Prevalence of Laws that Criminalize Homosexual Conduct and British Legal Origin}

One of the major findings of our data analysis is the correlation between having a British legal origin and having a law criminalizing homosexual conduct. Figure 1 shows the relative frequencies. Of those states with such a law, 57 per cent of them have a British legal origin. Of those states with a British legal origin, almost 70 per cent of them continue to criminalize homosexual conduct. We estimated the coefficient on British legal origin in this bivariate situation using logit with robust standard errors. Those states 
with a British legal origin are significantly more likely to have such a law. In fact, the predicted probability change (as British legal origin goes from 0 to 1 ) is from 0.24 to 0.7 , an increase of 46 percentage points. This relationship remains statistically significant and substantively large across numerous model specifications. Even after controlling for measures of religion, modernity, wealth, inequality, democracy, and human rights treaties signed, the effect size is large (see results in Table 3). In Model 1 with a criminalization dummy dependent variable, the increase in the predicted probability of such a law is from 0.04 to almost 0.80 , while other variables are held at their means. This increase of 75 percentage points dwarfs all other effect sizes in this model. After controlling for religiosity, using the smaller sample of 81 , the effect size is larger and is still significant at the $5 \%$ level $(\mathrm{p}=0.048)$. In a model including only British legal origin and religiosity as independent variables, British legal origin is highly significant $(\mathrm{p}=0.002)$. When using the ordinal punishment measure as the dependent variable and estimating effects using ordinal logit, the effect size is similarly large and significant, again even after controlling for religiosity.

\section{FIGURE 1 HERE}

What are the possible explanations for the large difference in the probability of having a law that criminalizes homosexual conduct between those states with and without a British legal origin? Given the data at hand, the relationship looks robust and strong. Why might this be the case? A selection effect seems unlikely; this would require that Britain colonized countries with some sort of predisposition to homophobia. The most plausible story involves a contingent and path dependent process of institutional evolution. This type of process is a prominent one in the discussion of colonial and postcolonial development (Mahoney, 2010). The most obvious pathway is that at the time when British colonies developed their legal systems, homosexuality was illegal in the United 
Kingdom and this law was transplanted into colonial law. Homosexuality was not legalized in England and Wales until 1967, after many colonies became independent and so any changes in British law were not similarly transferred into the colonial context. Absent a strong domestic constituency in favor of repeal of homophobic legislation, these laws remain on the books in ex-British colonies across the world.

\section{TABLE 4 HERE}

What about other colonial legal origins? Table 4 shows the distribution of decriminalization status by colonial status. The other wide-ranging global empire, the French, did not spread laws against sodomy or homosexuality because the Revolutionary Constituent Assembly of 1789-91 abrogated the previous law against sodomy in France when they adopted the French Penal Code of 1791 (Sibalis, 1996, p. 80). In a bivariate situation the coefficient on French legal origin is both negative and insignificant. After controlling for British legal origin, it becomes positive and significant $(\mathrm{p}=0.017)$ and its marginal effect on predicted probability is 35 percentage points. However, after controlling for the other independent variables it decreases in significance $(p=0.164)$ and becomes negative in terms of substantive effect. This relationship is thus not as robust as the one between British legal origin and criminalization of homosexual conduct laws.

One consequence of the large effect size of the British legal origin variable might be that the predicted probability of other independent variables varies according to whether they have a British legal origin. That is, the effect of another variable, say democracy, might be different for states whose laws have British legal origin compared to other states. Two other relatively significant variables in the full model are the amount of Sunni Muslims in the country and the countries' polity score. The effects of increased democracy are more pronounced for countries of British legal origin when the polity score goes from 0 to 10 than when it goes from -10 to 0 . That is, there is an increasing marginal effect of 
democracy for states that have laws with British legal origin. The opposite is true of states of other legal origins; there is a decreasing marginal effect of democracy for these states. However, this is not true for the effect of percentage of Sunni Muslims in a state. The marginal effect of an increasing percentage of Sunnis is declining for those with British legal origin and increasing for those without. In both of these situations, there are substantial differences between such states and others.

\section{Robustness tests}

It is possible that there could be an objection to our use of the La Porta et al's measure of legal origin (La Porta et al, 1999). This measure does not directly operationalize colonial heritage, and some of the states coded as having a British legal origin do not obviously fit the pattern of overseas formal imperialism. As a means of testing the sensitivity of the results to the particular coding of the legal origin variable, we used colonialism data from a variety of alternative sources. One prominent analysis from political science of the legacy of colonialism is Bernhard et al (Berhard et al, 2004). They investigated the correlation between the longevity of democratic political systems and experience of colonialism. They found that, compared to countries with other western overseas colonial legacies, British colonies have experienced longer periods of democracy. 'The British colonial legacy is quite conducive to survival [of democracy] compared with the others.' (Bernhard et al, 2004, p. 243). Using their coding for European Overseas Colonialism, excluding settler colonies and internal European colonies, the results are similar to those obtained using La Porta et al's data.

Compared to other colonies, British colonies are overwhelmingly more likely to have laws that criminalize homosexual conduct. None of the French of Spanish colonies identified by Bernhard et al currently have such laws. Of a total of 30 ex-colonies with such laws, 27 are ex-British colonies, and all but 3 ex-British colonies have such laws. 
Of the other colonies with such laws, 2 are Portuguese and 1 Dutch. Compared to all 155 other countries, ex-British colonies are 22 times more likely to have laws that criminalize homosexual conduct.

We estimated the full model using four additional measures of British colonial origin. The results can be compared in Figure 2. Each of the codings of British colonial status from Bernhard et al, Lange et al, and Klerman et al, as well as the aggregate measure of the union of all of these, produce coefficients that are similar in size and statistical significance to La Porta et al's British legal origin data.

\section{FIGURE 2 HERE}

\section{Effect of Colonial Legacy on Time to Decriminalization}

The second question, apart from whether and how much British colonies are more likely to have criminalization of homosexual conduct laws, is whether different colonial legacies had different effects in terms of the likelihood of decriminalization postdecolonization. That is, did British colonialism affect the long-term trajectory of LGBT rights in their colonies? Or has the imposition of such laws been easily shrugged off as soon as colonies became free to control their own destiny? In this section, we analyze the data to provide some evidence relevant to this question. One crucial fact to establish is whether it takes longer to decriminalize homosexual conduct after decolonization for British colonies. Another question is whether ex-British colonies are taking longer to decriminalize relative to the general global trend towards decriminalization. In order to answer these questions we generated two operationalizations of the concept of time to decriminalization; one based on the time colonies took to decriminalize after they gained their independence from the colonial state, and one based on the time all states took to decriminalize after World War II. 
The overall trend globally has been towards decriminalization. The differences by colonial identity are striking. Figures 3 and 4, and Table 5 and 6 show that the trends of decriminalization are different for French, Spanish, and British colonies.

FIGURE 3 HERE

FIGURE 4 HERE

TABLE 5 HERE

TABLE 6 HERE

First, we compared the time to decriminalization from decolonization for states that had been colonized by Britain, France, or Spain. The aim here is to see whether there has been some sort of specific legacy of British colonialism that has increased the time between becoming independent and decriminalization. We excluded from the analysis those colonies in which there is no evidence that there has ever been such a law, those colonies that decriminalized prior to independence, and those that have not yet decriminalized, which leaves us with 72 states. Then we defined a variable representing the time it took after a colony gained its independence for it to decriminalize homosexual conduct.

$$
\begin{gathered}
\text { Time to decriminalization after independence } \\
=\text { Year of decriminalization }- \text { Year of Independence }
\end{gathered}
$$

The mean time to decriminalization for British colonies was about 75 years. For French colonies it was 29 years. However, the mean time to decriminalization for Spanish colonies was 94 years, and for states that have another colonial heritage, the average time to decriminalization from independence is 76 years. British colonies thus do not appear at this level to be different from other types of states. 
Next, we compared the time to decriminalization after World War II for states who had a criminalization of homosexual conduct law in the year 1945. This eliminated states who did not criminalize homosexual conduct in the year 1945, as well as states that have not yet decriminalized (as of 2010). This left 60 states. No French colonies decriminalized during this time (although 3 recriminalized; see below). Then we defined a variable representing the time it took for a state to decriminalize after 1945. This was defined as:

Time to decriminalization $=$ Year of decriminalization $-1945^{10}$

The mean time to decriminalization for British colonies is 48 years. The mean time to decriminalization for colonies of Spanish colonies was 47 years. There is no appreciable difference between these two mean times to decriminalization.

It is true that there are more British colonies yet to decriminalize than any other category and almost as many states that have not yet decriminalized are British colonies than not. By itself, however, this does not yet mean that we have evidence that the British colonial experience has uniquely delayed decriminalization. If we define a third variable, the time from independence to the present (2010), for those states that have not yet decriminalized we can see that less time has passed from independence to decriminalization for British colonies than for French or for other states. This third variable will, of course, change in the future, but as of yet the evidence does not favor the idea that British colonies have a harder time decriminalizing than other types of states.

By 2008 no ex-Spanish colonies had laws that criminalize homosexual conduct. The distribution of decriminalization dates is instructive (See Figure 4). Of 18, 10 had decriminalized by 1900. Then, between 1900 and 1971 only Uruguay decriminalized. There were thus two waves in which ex-Spanish colonies got rid of such laws; one from 
1871 to 1900 and one from 1971 to 2008 . This complicates the issue of mean time to decriminalization. For the first wave, the mean time to decriminalization from independence was 44 years. For the second wave it was 136 years. It is not convincing that Spanish colonial heritage is generally important in determining when states decriminalize. The French colonial legacy is also complicated. As stated above, many French colonies did not receive criminalization of homosexual conduct laws from France. However, those French colonies that did have such a law have been very resistant to decriminalization. In one respect, ex-French colonies have a worse record than any other. Frank et al compiled data on states that criminalized homosexual conduct after World War II (Frank et al, 2009; Frank et al, 2010). Few states have enacted such laws after 1945 and three of these were ex-French colonies. Algeria, Cameroon and Mauritania enacted their criminalization laws in 1966, 1972 and 1984 respectively. None of these laws were spread by French colonialism as the countries were independent at the time. So, while French imperialism cannot be held responsible for the existence of such laws, the evidence for any post-independence benefits is unclear.

The evidence in favor of the hypothesis that British colonies took longer to decriminalize, by any measure, is thus inconclusive. British colonies on average did not take longer than other colonies to decriminalize after World War II, and while they may in general have taken longer than French colonies to repeal laws after gaining independence, Spanish colonies in general took much longer. Both hypotheses H2 and H3 should thus not be accepted. In the absence of other evidence, claims that British colonialism gave a country worse prospect for decriminalizing homosexual conduct than other colonialisms are without support.

\section{Conclusion}


Homosexuality remains a crime in many countries. While during the past half-century people in many countries have endeavored to remove such repressive legislation, the decriminalization of homosexual conduct is an uneven process throughout the world. In this article, we investigated the effect of British colonialism on criminalization/decriminalization of homosexual conduct, and indeed our finding supports the argument that British colonial experience has left a damaging legacy on its former colonies. Countries that were once colonized by Britain are more likely to have such laws in their law books. The fact that many countries have such legislation on their law books can be attributed to their inheritance of a specific set of penal codes imposed on them by the British colonial administration. However, our finding also indicates that the speed of decriminalization of homosexual conduct is not systematically slower for former British colonies than other former European colonies. This finding suggests that if a country has such a law, the longevity of the law is not dependent upon a particular type of colonialism. Although we did find that being a colony of any type prolongs the decriminalization process compared to non-colonies, we did not find evidence supporting the argument that British colonialism has special effect on the timing of decriminalization of homosexual conduct.

Certainly, the contemporary global politics of decriminalization of homosexual conduct is a complex process, with many international factors not incorporated within our analysis. ${ }^{11}$ Efforts by various international NGOs and activism networks, as well as various UN related initiatives, have definitely played tremendous role in pushing for the decriminalization of homosexuality around the world. For example, the Human Dignity Trust was founded in the UK in 2011 to establish global legal networks to challenge the legality of criminalization of homosexuality around the world. Acknowledging the effect of those global factors, what we have done in this paper is focusing on the macro level, with specifically engagement with the British colonial legacy hypothesis. This study on 
the impact of British colonialism on LGBT politics is further an engagement of the broader literature on political institutions, particularly the legacies of colonialism. In contrast with previous studies that lauded the positive contribution of British colonialism in promoting economic development and spreading democratic values, our finding highlights a dark underside of the British colonial legacy that has been extremely detrimental to the rights and freedom of LGBT people around the world. By imposing on its colonies a set of penal codes that specifically targeted homosexual conduct, when until that time some cultures did not have the same attitudes towards such punishment, the British Empire appears substantially responsible for the current state of this particular issue. At a time when there is a global trend to offer equal rights to LGBT people, highlighting this 'alien' origin of laws that criminalize homosexual conduct as a legacy of colonial imposition might help clear some unnecessary hurdles in the continuing effort to decriminalize homosexuality.

Notes

1. For example, The Human Rights Campaign, which is based in Washington, DC, is America's largest civil rights organization working to achieve LGBT equality and strives to end discrimination against LGBT people in the US. http://www.hrc.org/

2. http://www.nytimes.com/2011/12/07/world/united-states-to-use-aid-to-promote-gayrights-abroad.html?pagewanted=all 
3. One major caveat we have to point out is that in the paper we only look at whether a country has a law that criminalizes homosexual conduct. We do not construct our data on the basis of whether such laws are applied in reality. This is a big difference because there are many countries that might have such a law but they rarely if ever apply them. We acknowledge this is a big limit in our analysis. However, due to data limit, we cannot empirically verify this issue for every country in the world.

4. ILGA's website can be accessed at ilga.org

\section{5. http://ilga.org/ilga/en/countries/IRAN,\%20ISLAMIC\%20REPUBLIC\%20OF/Law}

6. According to Human Rights Watch, the countries that directly inherited laws that criminalizes homosexual conduct from the British Empire include: Australia, Bangladesh, Bhutan, Botswana, Brunei, Fiji, Gambia, Ghana, Hong Kong, India, Kenya, Kiribati, Lesotho, Malawi, Malaysia, Maldives, Marshall Islands, Mauritius, Myanmar (Burma), Nauru, New Zealand, Nigeria, Pakistan, Papua New Guinea, Seychelles, Sierra Leone, Singapore, Solomon Islands, Somalia, Sri Lanka, Sudan, Swaziland, Tanzania, Tonga, Tuvalu, Uganda, Western Samoa, Zambia, and Zimbabwe (Gupta, 2004, p. 6).

7. For access to the IPC, see http://districtcourtallahabad.up.nic.in/articles/IPC.pdf

8. That is, if a country was identified as a colony by any of these sources, it was coded as a colony, even if only two or one source identified it.

9. For the purpose of this analysis, those states still have $\mathrm{CHC}$ laws were given an end year of 2010.

10. Some of the ex-British colonies have outlier TTDI values. These are the settler colonies of the United States, Canada, Australia, New Zealand, and South Africa. Excluding these states $\mathrm{f}$ rom the analysis does not substantially change the coefficient values for the colonial legacy variables.

11. Due to space limit, this article cannot adequately address the existing vast historical and anthropological literature on homosexuality and colonialism, nor can it incorporate studies in international theory that specifically deals with the globalization of LGBT politics. Further research is indeed needed to combine our positivist approach with more contextual analyses that are more sensitive to specific time and locality. 


\section{References}

Alam, M. S. (1994) 'Colonialism, Decolonization and Growth Rates: Theory and Empirical Evidence', Cambridge Journal of Economics, 18 (3), 235-57.

Aldrich, R. (2003) Colonialism and Homosexuality. London and New York: Routledge.

Alesina, A., Devleeschauwer, A., Easterly, W., Kurlat, S. and Wacziarg, R. (2003)

'Fractionalization', Journal of Economic Growth, 8, 155-94.

Amnesty International, 'Love, Hate and the Law: Decriminalizing Homosexuality,' (London: Amnesty International, 2008).

Amsden, A. (1989) Asia's Next Giant: South Korea and Asian Industrialization. New York: Oxford University Press.

Andersen, R. and Fetner, T. (2008) 'Economic Inequality and Intolerance: Attitudes Towards Homosexuality in 35 Democracies', American Journal of Political Science, 52 (4), 942-58.

Anheier, H. K., Kaldor, M. and Glasius, M. (2006) Global Civil Society 2006/2007. London: Sage Publications Ltd.

Barry, B. (2010) 'Gay Couple Convicted in Malawi', The New York Times, May 18.

Bernhard, M., Reenock, C. and Nordstrom, T. (2004) 'The Legacy of Western Overseas Colonialism on Democratic Survival', International Studies Quarterly, 48 (1), 225-50.

Bertocchi, G. and Canova, F. (2002) 'Did Colonization Matter for Growth? An Empirical Exploration into the Historical Causes of Africa's Underdevelopment', European Economic Review, 46, 1851-71.

Blondel, J. (1972) Comparing Political Systems. New York: Praeger.

Boon, C. (1992) Merchant Capital and the Roots of State Power in Senegal, 1930-1985. New York: Cambridge University Press.

Bruce-Jones, E. and Itaborohy, L. P. (2011) 'State-Sponsored Homophobia: A World Suvey of Laws Criminalising Same-Sex Sexual Acts between Consenting Adults', The International Lesbian, gay, Bisexual, Trans and Intersex Association (ILGA).

Burack, C. (2008) Sin, Sex, and Democracy: Antigay Rhetoric and the Christian Right. Albany, NY: State University of New York Press.

Canning, P. (2011) 'Northern Cyprus to Decriminalize Homosexuality', LGBTQ Nation, December 14. 
Crompton, L. (2003) Homosexuality and Civilization. Cambridge, MA: Harvard University Press.

D'Souza, E. (2002) 'Two Cheers for Colonialism', Chronicle Review: The Chronicle of Higher Education, May 10.

DeYoung, J. B. (2000) Homosexuality: Contemporary Claims Examined in Light of the Bible and Other Ancient Literature and Law. Grand Rapids, MI: Kregel Publications.

Duran, K. (1993) 'Homosexuality in Islam', in A. Swidler (ed), Homosexuality and World Religions. Valley Forge, PA: Trinity Press International.

Ferguson, N. (2002) Empire: The Rise and Demise of the British World Order and the Lessons for Global Power. New York: Basic Books.

Fieldhouse, D. K. (1966) The Colonial Empires from the 18th Century. New York: Dell Publishing.

Fone, B. (2000) Homophobia: A History, New York: Metropolitan Press.

Frank, D. J., Camp, B. J. and Boutcher, S. A. (2010) 'Worldwide Trends in the Criminal Regulation of Sex, 1945 to 2005', American Sociological Review, 75 (6), 867-93.

Frank, D. J., Boutcher, S. A. and Camp, B. J. (2009) 'The Reform of Sodomy Laws: From a World Society Perspective', in S. Barclay, M. Berstein, A. M. Marshall (eds), Queer Mobilizations: Lgbt Activists Confront the Law. New York: New York University Press.

Friedland, M. L. (1992) 'Codification in the Commonwealth: Earlier Efforts', Commonwealth Law Bulletin, 18 (3), p. 1172

Goldberg-Hiller, J. (2005) 'The Limits to Union: Same-Sex Marriage and the Politics of Civil Rights', in A. Arbor (ed.), MI: The University of Michigan Press

Goodman, R. (2001) 'Beyond the Enforcement Principle: Sodomy Laws, Social Norms, and Social Panoptics', California Law Review, 89, 643-740.

Grier, R.M. (1999) 'Colonial Legacies and Economic Growth', Public Choice, 98, 31735 .

Gupta, A. (2008) This Alien Legacy: The Origins Of 'Sodomy' Laws in British Colonialism. New York: Human Rights Watch.

Herman, D. (2000) 'The Gay Agenda Is the Devil's Agenda: The Christian Right's Vision and the Role of the State', in C. Rimmermann, K. Wald and C. Wilcox (eds), The Politics of Gay Rights. Chicago: The University of Chicago Press. 
Huff, W.G. (1994) The Economic Growth of Singapore: Trade and Development in the Twentieth Century. New York: Cambridge University Press.

Huntington, S. (1984) 'Will More Countries Become Democratic?' Political Science Quarterly, 99 (2), 193-218.

Inglehart, R. (1987) 'Value Change in Industrial Societies', American Political Science Review, 81 (4), 1289-1319.

Inglehart, R. (1990) Culture Shift in Advanced Industrial Society. Princeton, NJ:

Princeton University Press.

Inglehart, R. (1997) Modernization and Postmodernization: Cultural, Economic and Political Change in 43 Societies. Princeton, NJ: Princeton University Press.

Inglehart, R. and Welzel, C. (2002) 'Political Culture and Democracy', in H. Wiarda (ed), New Directions in Comparative Politics. Boulder, CO: Westview Press.

Jain, D. (2013) 'Impact of the Decriminalization of Homosexuality in Delhi: An Empirical Study', The Arkansas Journal of Social Change and Public Service, January 13.

Kim, R. (2005) 'Witnesses to an Execution', The Nation, August 7.

Kohli, A. (2004) State-Directed Development: Political Power and Industralization in the Global Periphery. New York: Cambridge University Press.

Kollman, K. (2007) 'Same-Sex Unions: The Globalization of an Idea', International Studies Quarterly, 51 (2), 329-57.

Kymlicka, W. (1995) The Rights of Minority Cultures. Oxford: Oxford University Press.

Lange, M. (2009) Lineages of Despotism and Development: British Colonialism and State Power. Chicago: The University of Chicago Press.

Lange, M., Mahoney, J. and vom Hau, M. (2006) 'Colonialism and Development: A Comparative Analysis of Spanish and British Colonies', American Journal of Sociology, 111 (5), 1412-62.

La Porta, R., Lopez-de-Silanes, F., Shleifer, A. and Vishny, R.W. (1999) 'The Quality of Government', Journal of Economics, Law and Organization, 15, 222-79.

La Porta, R., Lopez-de-Silanes, F., Pop-eleches, C., Shleifer, A. (2004) 'Judicial Checks and Balances', Journal of Political Economy, 112 (2), 445-70. 
Landes, D. S. (1998) The Weath and Poverty of Nations: Why Some Are So Rich and Some So Poor. New York: W. W. Norton \& Company.

Lipset, S. M., Seong, K.R. and Torres, J. C. (1993) 'A Comparative Analysis of the Social Requisites of Democracy', International Social Science Journal, 45 (2), 155-75.

Litteauer, D. (2012) 'Four Iranian Men due to be Hanged for Sodomy', Pink News, May 12.

Mahoney, J. (2000) 'Path Dependence in Historical Sociology', Theory and Society, 29 (4), 507-48.

Mahoney, J. (2010) Colonialism and Postcolonial Development: Spanish America in Comparative Perspective. Cambridge: Cambridge University Press.

Mamdani, M. (1996) Citizen and Subject. Princeton, NJ: Princeton University Press.

McClintock, A. (1995) Imperial Leather: Race, Gender, and Sexuality in the Colonial Context. London and New York: Routledge.

Miles, W. (1994) Housaland Divided: Colonialism and Independence in Nigeria and Niger. Ithaca, NY: Cornell University Press.

Morris, H. F. (1974) 'A History of the Adoption of Codes of Criminal Law and Procedure in British Colonial Africa, 1876-1935', Journal of African Law, 18 (1), 6-23.

Norris, P. and Inglehart, R. (2009) Cosmopolitan Communications: Cultural Diversity in a Globalized World. Cambridge: Cambridge University Press.

Olsson, O. (2009) 'On the Democratic Legacy of Colonialism', Journal of Comparative Economics, 37, 534-51.

Pagden, A. (1995) Lords of All the World: Ideologies of Empire in Spain, Britain and France, C. 1500 - C. 1800. New Haven, CT: Yale University Press.

Pierson, P. (2000) 'Increasing Returns, Path Dependence, and the Study of Politics', American Political Science Review, 94 (2), 251-67.

Sanders, D. E. (2009) ' 377 and the Unnatural Afterlife of British Colonialism in Asia', Asian Journal of Comparative Law, 4 (1), 1-30.

Schmitt, A.and Sofer, J. (1992) Sexuality and Eroticism among Males in Moslem Societies. Binghampton, NY: Haworth Press. 
Sibalis, M. (1996) 'The Regulation of Male Homosexuality in Revolutionary and Napoleonic France', in J. Merick, B. T. Ragan (eds), Homosexuality in Modern France. New York: Oxford University Press.

Stoler, A. L. (2002) Carnal Knowledge and Imperial Power: Race and the Intimate in Colonial Rule. Berkeley and Los Angeles, CA: University of California Press.

Tielman, R. and Hammelburg, H. (1993) 'World Survey on the Social and Legal Position of Gays and Lesbians', in R. Tielman, A. Hendriks and E. van der Veen (eds), The Third Pink Book: A Global View of Lesbian and Gay Liberation and Oppression. Buffalo, NY: Prometheus Books.

Waaldijk, K. (2009) Legal Recognition of Homosexual Orientation in the Countries of the World. Leiden, the Netherlands: Leiden Law School.

Wade, R. (1990) Governing the Market: Economic Theory and the Role of Government in East Asian Industrialization. Princeton, NJ: Princeton University Press.

Wilets, J. D. (2010) 'Divergence between Lgbti Legal, Political, and Social Progress in the Caribbean and Latin America', in J. Corrales and M. Pecheny (eds), The Politics of Sexuality in Latin America: A Reader on Lesbian, Gay, Bisexual, and Transgender Rights. Pittsburgh, PA: University of Pittsburgh Press.

Wilets, J. D. (1994) 'International Human Rights Law and Sexual Orientation', Hastings International and Comparative Law Review, 18 (1), 1-120.

Young, C. (1994) The African Colonial State in Comparative Perspective. New Haven, CT: Yale University Press. 